\title{
Plasma remediation of trichloroethylene in silent discharge plasmas
}

\author{
Diane Evans \\ University of Illinois, Department of Electrical and Computer Engineering, 1406 West Green Street, \\ Urbana, Illinois 61801 \\ Louis A. Rosocha, Graydon K. Anderson, and John J. Coogan \\ Los Alamos National Laboratory, Chemical and Laser Science Division, Los Alamos, New Mexico 87545 \\ Mark J. Kushnera) \\ University of Illinois, Department of Electrical and Computer Engineering, 1406 West Green Street, \\ Urbana, Illinois 61801
}

(Received 19 April 1993; accepted for publication 15 July 1993)

\begin{abstract}
Plasma destruction of toxins, and volatile organic compounds in particular, from gas streams is receiving increased attention as an energy efficient means to remediate those compounds. In this regard, remediation of trichloroethylene (TCE) in silent discharge plasmas has been experimentally and theoretically investigated. We found that TCE can be removed from $\mathrm{Ar} / \mathrm{O}_{2}$ gas streams at atmospheric pressure with an energy efficiency of $15-20 \mathrm{ppm} /\left(\mathrm{mJ} / \mathrm{cm}^{3}\right)$, or 2-3 $\mathrm{kW} \mathrm{h} \mathrm{kg}{ }^{-1}$. The majority of the $\mathrm{Cl}$ from TCE is converted to $\mathrm{HCl}, \mathrm{Cl}_{2}$, and $\mathrm{COCl}_{2}$, which can be removed from the gas stream by a water bubbler. The destruction efficiency of TCE is smaller in humid mixtures compared to dry mixtures due to interception of reactive intermediates by $\mathrm{OH}$ radicals.
\end{abstract}

\section{INTRODUCTION}

Increasing environmental awareness has motivated research into alternative methods to remediate toxic wastes. In particular, low temperature plasmas have been investigated to remove toxins from atmospheric pressure gas streams. Low temperature plasmas are attractive in this regard due to their high efficiency for producing radicals and oxidizing agents. For example, electron beam, corona, microwave, and dielectric barrier discharges have been studied to remediate $\mathrm{SO}_{2}$ and $\mathrm{NO}_{x},{ }^{1-7} \mathrm{CCl}_{4},{ }^{8,9}$ and $\mathrm{CH}_{2} \mathrm{O}^{10,11}$ Dielectric barrier discharges, or silent discharge plasmas (SDPs), are particularly attractive for this purpose due to their ability to operate stably at atmospheric pressure and their relative maturity due to their use as commercial ozone generators. ${ }^{12-14}$

Volatile organic compounds (VOCs) and solvents are candidates for plasma remediation due to new restrictions on their combustion and disposal. Complex molecules often require many steps of oxidation or reactions to produce the desired end products. Considerable attention must then be paid to the intermediate species and other possibly undesirable end products since they might require further processing. For example, $\mathrm{CCl}_{4}$ has been removed from air streams using $e$-beam excitation with high efficiency $(\mathrm{eV} /$ molecule) while producing phosgene $\left(\mathrm{COCl}_{2}\right)$ as one of many end products. ${ }^{9}$ Plasma remediation under these conditions may then require closed cycle systems or second stage treatment where the undesirable end products are separated from the gas stream before exhausting to the atmosphere. Ideally, the end products are either more easily remediated than the original toxin, or have a market value which motivates their recovery.

Trichloroethylene $\left(\mathrm{C}_{2} \mathrm{HCl}_{3}\right.$, or TCE) is a common industrial solvent for which alternate remediation methods are being sought. Plasma remediation is attractive since

\footnotetext{
${ }^{\text {a) }}$ Author to whom correspondence should be addressed.
}

TCE in the gas phase reacts with atomic oxygen and hydroxyl radicals which are efficiently produced in low temperature plasmas containing $\mathrm{O}_{2}$ and $\mathrm{H}_{2} \mathrm{O}$. The desired reaction stoichiometry is

$$
\begin{aligned}
& \mathrm{C}_{2} \mathrm{HCl}_{3}+4 \mathrm{OH} \rightarrow \mathrm{CO}_{2}+3 \mathrm{HCl}+\mathrm{H}_{2}, \\
& \mathrm{C}_{2} \mathrm{HCl}_{3}+4 \mathrm{O} \rightarrow 2 \mathrm{CO}_{2}+\mathrm{HCl}+\mathrm{Cl}_{2} .
\end{aligned}
$$

The end products $\mathrm{CO}_{2}$ and $\mathrm{H}_{2}$ can be exhausted to the atmosphere. $\mathrm{HCl}$ and $\mathrm{Cl}_{2}$ are easily removed from the gas stream by a water spray or bubbling. This creates an acid which can be neutralized with a base or recovered for recycling. This stoichiometry is, however, difficult to achieve with high efficiency at the low gas temperatures $(300-500$ $\mathrm{K})$ at which nonthermal plasmas are operated. As explained below, at low temperatures the TCE is converted to intermediate products which may then require second stage treatment. For these reasons, a closed cycle system may be desirable. Although a closed cycle system adds complexity, it also affords the opportunity to use gas mixtures other than air. For example, in the closed cycle system schematically shown in Fig. 1, an $\mathrm{Ar} / \mathrm{O}_{2} / \mathrm{H}_{2} \mathrm{O}$ gas mixture is used. TCE is volatilized and injected to levels of 100 's-1000 ppm. The gas stream flows through the plasma generator, a water bubbler (to capture end products and humidify the gas), a pump/heat exchanger, and a gas bleed/injector to remove gaseous products and add the working mixture.

In this article, we describe an experimental and computational study of the plasma remediation of TCE using SDPs. We found that TCE was remediated with high effciency in atmospheric pressure $\mathrm{Ar} / \mathrm{O}_{2} / \mathrm{H}_{2} \mathrm{O}$ mixtures. The process was more efficient in dry mixtures [removal rate (TCE remediated/energy deposition) $\geqslant 10 \mathrm{ppm} /(\mathrm{mJ} /$ $\left.\left.\mathrm{cm}^{3}\right)\right]$ than wet mixtures $\left[<20 \mathrm{ppm} /\left(\mathrm{mJ} / \mathrm{cm}^{3}\right)\right]$. The $\mathrm{ClO}$ radical is an important intermediate which oxidizes TCE. Its consumption by $\mathrm{OH}$ radicals is largely responsible for the lower rate of remediation in wet mixtures compared to 


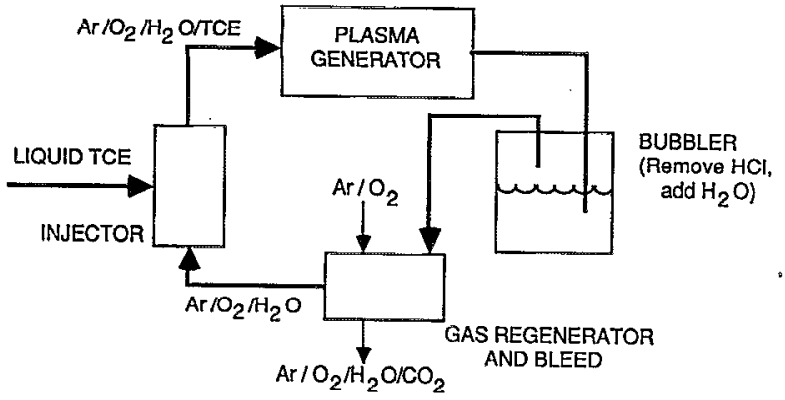

FIG. 1. Schematic of a closed cycle plasma remediation system. Closed cycle systems may be necessary when the effluent requires second stage treament.

dry mixtures. We also found that the majority of the $\mathrm{Cl}$ from the TCE is ultimately bound in molecules other than $\mathrm{HCl}$, thereby requiring a second stage treatment for total remediation.

In Sec. II, the experimental apparatus will be described followed by a description of the model and reaction mechanisms in Sec. III and IV. Our experimental and calculated results will be discussed in Sec. V, followed by our con cluding remarks in Sec. VI.

\section{DESCRIPTION OF THE EXPERIMENT}

Dielectric barrier discharges, or silent discharge plasmas (SDPs) are well suited to plasma remediation of atmospheric pressure gas streams. ${ }^{12-15}$ In a SDP, one or both of the electrodes are covered with dielectric layers (e.g., glass) which separate them from the gas. In conventional atmospheric pressure discharges, arcing results in localized heating and nonuniform processing of the gas. In a SDP, the dielectric surfaces serve the role of a capacitor in series with the plasma. The plasma in a SDP consists of a "forest" of microstreamers. When the microstreamers cross the gap and impinge on the dielectric, the dielectric charges. Since the transverse mobility of charge on the dielectric is extremely low, the charging of the dielectric is restricted to the vicinity of the streamer. When the local dielectric charges and reduces the voltage across the gap, the streamer is quenched, thereby preventing formation of an arc. The streamers are typically 10 's $\mathrm{ns}$ in duration and 100 's $\mu \mathrm{m}$ in diameter. Ideally, the streamers randomly appear throughout the discharge volume providing, on the average, uniform processing. The SDP plasma is operated at 10 's $\mathrm{Hz}$ to a few $\mathrm{kHz}$, so processing of the gas is performed over many cycles.

A silent discharge apparatus was constructed to investigate the plasma remediation of TCE, various chlorofluorocarbons and $\mathrm{CCl}_{4}$. The results of the latter studies will be reported elsewhere. The SDP cell has a planar geometry, as shown in Fig. 2, and has approximate dimensions of $71 \mathrm{~cm}$ in length, $18 \mathrm{~cm}$ in width, and a $0.25 \mathrm{~cm}$ gap, yielding a mean discharge area of $1236 \mathrm{~cm}^{2}$ and an active discharge volume of $310 \mathrm{~cm}^{3}$. The power supply is a series inverter which switches charged capacitors through a pulse trans former by means of high-power thyristors. The unit is ca-

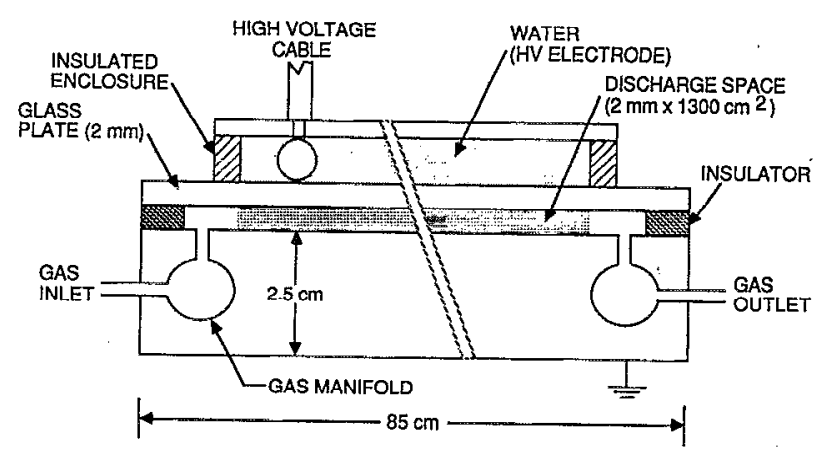

FIG. 2. Schematic of the experimental silent discharge plasma generator. The plasma zone of the flat panel apparatus is $72 \mathrm{~cm}$ (flow direction) $\times 18 \mathrm{~cm}$. The barrier-electrode gap is $0.2 \mathrm{~cm}$.

pable of providing $4 \mathrm{~kW}$ at pulse repetition frequencies of up to $4.5 \mathrm{kHz}$. Typical flow rates $(10 \mathrm{slm})$ and power deposition $(200 \mathrm{~W})$ yielded electrical energy deposition up to $1.2 \mathrm{~J} \mathrm{~cm}^{-3}$ and power densities of $0.16 \mathrm{~W} \mathrm{~cm}^{-2}$.

The SDP cell uses a single barrier consisting of a $2 \mathrm{~mm}$ glass plate opposing the metallic base plate. The upper electrode is a water pool in which a screen is immersed. The screen is connected to a high voltage cable from the power supply. This provides an evenly distributed voltage to the entire surface of the barrier. The gas streams are generated using standard gas flow regulators. The gas flow is humidified by bubbling the influent stream through a water chamber. Products in the effluent were detected using a gas chromatograph and mass spectrometer.

\section{DESCRIPTION OF THE MODEL}

The model is functionally similar to that described in Refs. 11, 16, and 17. The simulation consists of three components: a circuit model, a solution of Boltzmann's equation for the electron energy distribution (EED), and a plasma chemistry model. The circuit model computes the applied voltage to the plasma, which is used to solve Boltzmann's equation for the EED using a two-term spherical harmonic expansion. The EED is then used to calculate electron impact rate coefficients. The time derivatives of the densities of atomic, molecular, and ionic species in the plasma are calculated from the electron impact rate coefficients, temperature-dependent rate coefficients, and the species' densities. The conductivity of the plasma is then computed and used to calculate the resistance of the plasma for use in solving the circuit equations.

The plasma chemistry model consists of 97 species and 385 reactions. The reactions we used for plasmas sustained in humid air and oxygen mixtures are the same as in the previously discussed models in Refs. 16 and 17. The reactions we included for electron impact excitation and heavy particle collisions of excited states and ions of Ar are the same as found in high pressure excimer lasers, and are discussed in Ref. 18. The important reactions and rate coefficients we used for the addition of TCE to those gas mixtures, and for reactions of $\mathrm{Ar}$ excited states with $\mathrm{O}_{2}$, are listed in Table I. Our reaction scheme for TCE is based 
TABLE I. Partial listing of reactions included in the model for $\mathrm{C}_{2} \mathrm{HCl}_{3}$ remediation. ${ }^{2}$

\begin{tabular}{|c|c|c|}
\hline Process & Rate coefficient $t^{b}$ & Ref. \\
\hline \multicolumn{3}{|l|}{ Reactions with $\mathrm{C}_{2} \mathrm{HCl}_{3}$} \\
\hline $\mathrm{C}_{2} \mathrm{HCl}_{3}+\mathrm{Cl} \rightarrow \mathrm{C}_{2} \mathrm{Cl}_{3}+\mathrm{HCl}$ & $3.31(-12) \exp (-2525 / T)$ & 19 \\
\hline $\mathrm{C}_{2} \mathrm{HCl}_{3}+\mathrm{O} \rightarrow \mathrm{CHOCl}+\mathrm{CCl}_{2}$ & $1.66(-11) \exp (-1010 / T)$ & 19 \\
\hline $\mathrm{C}_{2} \mathrm{HCl}_{3}+\mathrm{OH} \rightarrow \mathrm{CHCl}_{2} \mathrm{COCl}+\mathrm{H}$ & $5.25(-14) \exp (455 / T)$ & 19. \\
\hline $\mathrm{C}_{2} \mathrm{HCl}_{3}+\mathrm{ClO} \rightarrow \mathrm{CHCl}_{2} \mathrm{COCl}+\mathrm{Cl}$ & $1.66(-13) \exp (-1010 / T)$ & 19 \\
\hline $\mathrm{C}_{2} \mathrm{HCl}_{3}+\mathrm{CHCl}_{2} \rightarrow \mathrm{CHCl}_{3}+\mathrm{C}_{2} \mathrm{HCl}_{2}$ & $4.17(-12) \exp (-2525 / T)$ & 19 \\
\hline $\mathrm{C}_{2} \mathrm{HCl}_{3}+\mathrm{ClO} \rightarrow \mathrm{CHCl}_{2}+\mathrm{COCl}_{2}$ & $1.67(-11) \exp (-505 / T)$ & 19 \\
\hline $\mathrm{C}_{2} \mathrm{HCl}_{3}+\mathrm{CCl}_{3} \rightarrow \mathrm{C}_{3} \mathrm{HCl}_{6}$ & $9.56(-13) \exp (-2677 / T)$ & 19 \\
\hline $\mathrm{C}_{2} \mathrm{HCl}_{3}+\mathrm{C}_{2} \mathrm{Cl}_{3} \rightarrow \mathrm{C}_{4} \mathrm{HCl}_{6}$ & $1.67(-12) \exp (-2525 / T)$ & 19 \\
\hline $\mathrm{C}_{2} \mathrm{HCl}_{3}+\mathrm{CCl}_{3} \rightarrow \mathrm{CCl}_{4}+\mathrm{C}_{2} \mathrm{HCl}_{2}$ & $5.25(-13) \operatorname{cxp}(-4040 / T)$ & 19 \\
\hline $\mathrm{C}_{2} \mathrm{HCl}_{3}+\mathrm{OH} \rightarrow \mathrm{C}_{2} \mathrm{Cl}_{3}+\mathrm{H}_{2} \mathrm{O}$ & $1.66(-12) \exp (-1010 / T)$ & 19 \\
\hline $\mathrm{C}_{2} \mathrm{HCl}_{3}+\mathrm{OH} \rightarrow \mathrm{CHCl}_{2}+\mathrm{CHOCl}$ & $1.66(-12) \exp (-505 / T)$ & 19 \\
\hline $\mathrm{C}_{2} \mathrm{HCl}_{3}+\mathrm{ClO} \rightarrow \mathrm{CCl}_{3}+\mathrm{CHOCl}$ & $1.66(-11) \exp (-6818 / T)$ & 19 \\
\hline \multicolumn{3}{|c|}{ Additional reactions with and producing $\mathrm{COCl}_{2}$} \\
\hline $\mathrm{COCl}_{2}+\mathrm{O} \rightarrow \mathrm{ClO}+\mathrm{COCl}$ & $9.96(-15)$ & 22 \\
\hline $\mathrm{COCl}_{2}+\mathrm{O}\left({ }^{1} D\right) \rightarrow \mathrm{ClO}+\mathrm{COCl}$ & $1.00(-10)$ & $22^{c}$ \\
\hline $\mathrm{COCl}_{2}+\mathrm{H} \rightarrow \mathrm{COCl}+\mathrm{HCl}$ & $1.66(-11) \exp (-1010 / T)$ & 19 \\
\hline $\mathrm{CCl}_{3}+\mathrm{O} \rightarrow \mathrm{Cl}+\mathrm{COCl}_{2}$ & $4.15(-11)$ & 22 \\
\hline $\mathrm{CCl}_{3}+\mathrm{OH} \rightarrow \mathrm{HCl}+\mathrm{COCl}_{2}$ & $1.00(-11)$ & $\mathrm{c}$ \\
\hline $\mathrm{CCl}_{3} \mathrm{O} \rightarrow \mathrm{Cl}+\mathrm{COCl}_{2}$ & $1.00(5) \mathrm{s}^{-1}$ & 22 \\
\hline $\mathrm{CHCl}_{3}+\mathrm{O} \rightarrow \mathrm{HCl}+\mathrm{COCl}_{2}$ & $4.79(-12) \exp (-2525 / T)$ & 19 \\
\hline $\mathrm{C}_{2} \mathrm{Cl}_{3}+\mathrm{O}_{2} \rightarrow \mathrm{COCl}+\mathrm{COCl}_{2}$ & $5.25(-13) \exp (-2525 / T)$ & 19 \\
\hline $\mathrm{C}_{2} \mathrm{Cl}_{3}+\mathrm{O}_{2} \rightarrow \mathrm{COCl}+\mathrm{COCl}_{2}$ & $1.66(-13) \exp (-2525 / T)$ & 19 \\
\hline $\mathrm{C}_{2} \mathrm{Cl}_{4}+\mathrm{O} \rightarrow \mathrm{CCl}_{2}+\mathrm{COCl}_{2}$ & $1.66(-11) \exp (-2525 / T)$ & 19 \\
\hline $\mathrm{C}_{2} \mathrm{Cl}_{4}+\mathrm{OH} \rightarrow \mathrm{CHCl}_{2}+\mathrm{COCl}_{2}$ & $1.66(-11) \exp (-1010 / T)$ & 19 \\
\hline $\mathrm{C}_{2} \mathrm{Cl}_{4}+\mathrm{ClO} \rightarrow \mathrm{CCl}_{3}+\mathrm{COCl}_{2}$ & $1.66(-11) \exp (-1010 / T)$ & 19 \\
\hline \multicolumn{3}{|c|}{ Additional reactions with and producing $\mathrm{ClO}$} \\
\hline $\mathrm{ClO}+\mathrm{O} \rightarrow \mathrm{Cl}+\mathrm{O}_{2}$ & $3.00(-11) \exp (70 / T)$ & 22 \\
\hline $\mathrm{ClO}+\mathrm{O}_{3} \rightarrow \mathrm{ClOO}+\mathrm{O}_{2}$ & $1.00(-12) \exp (-4000 / T)$ & 22 \\
\hline $\mathrm{ClO}+\mathrm{OH} \rightarrow \mathrm{HCl}+\mathrm{O}_{2}$ & $1-5(-11)$ & $22^{\mathrm{d}, e}$ \\
\hline $\mathrm{ClO}+\mathrm{H}_{2} \rightarrow \mathrm{HCl}+\mathrm{OH}$ & $5.00(-16)$ & 22 \\
\hline $\mathrm{ClO}+\mathrm{HO}_{2} \rightarrow \mathrm{HOCl}+\mathrm{O}_{2}$ & $5.55(-13) \exp (670 / T)$ & 22 \\
\hline $\mathrm{ClO}+\mathrm{ClO} \rightarrow \mathrm{Cl}_{2}+\mathrm{O}_{2}$ & $4.90(-15)$ & 22 \\
\hline $\mathrm{ClO}+\mathrm{ClO} \rightarrow \mathrm{Cl}+\mathrm{ClOO}$ & $3.40(-15)$ & 22 \\
\hline $\mathrm{ClO}+\mathrm{CO} \rightarrow \mathrm{CO}_{2}+\mathrm{Cl}$ & $1.00(-12) \exp (-3737 / T)$ & 19 \\
\hline $\mathrm{ClO}+\mathrm{COCl} \rightarrow \mathrm{CO}+\mathrm{Cl}_{2} \mathrm{O}$ & $1.66(-10)$ & 19 \\
\hline $\mathrm{ClO}+\mathrm{COCl} \rightarrow \mathrm{CO}_{2}+\mathrm{Cl}_{2}$ & $1.66(-10)$ & 19 \\
\hline $\mathrm{ClO}+\mathrm{C}_{2} \mathrm{Cl}_{2} \rightarrow \mathrm{CO}+\mathrm{CCl}_{3}$ & $1.66(-13)$ & 19 \\
\hline $\mathrm{ClO}+\mathrm{C}_{2} \mathrm{Cl}_{3} \rightarrow \mathrm{CO}+\mathrm{CCl}_{4}$ & $1.66(-11)$ & 19 \\
\hline $\mathrm{ClO}+\mathrm{C}_{2} \mathrm{Cl}_{4} \rightarrow \mathrm{CCl}_{3} \mathrm{COCl}+\mathrm{Cl}$ & $1.66(-13) \exp (-2525 / T)$ & 19 \\
\hline $\mathrm{Cl}+\mathrm{O}_{3} \rightarrow \mathrm{O}_{2}+\mathrm{ClO}$ & $2.61(-11) \exp (-237 / T)$ & 22 \\
\hline $\mathrm{Cl}+\mathrm{HOCl} \rightarrow \mathrm{HCl}+\mathrm{ClO}$ & $3.00(-12) \exp (-130 / T)$ & 22 \\
\hline $\mathrm{Cl}+\mathrm{ClOO} \rightarrow \mathrm{ClO}+\mathrm{ClO}$ & $8.00(-12)$ & 22 \\
\hline $\mathrm{Cl}+\mathrm{HO}_{2} \rightarrow \mathrm{OH}+\mathrm{ClO}$ & $1.05(-10) \exp (-857 / T)$ & 19 \\
\hline $\mathrm{Cl}_{2}+\mathrm{O} \rightarrow \mathrm{Cl}+\mathrm{ClO}$ & $2.09(-11) \exp (-1414 / T)$ & 20 \\
\hline $\mathrm{Cl}_{2} \mathrm{O}+\mathrm{O} \rightarrow \mathrm{ClO}+\mathrm{ClO}$ & $3.11(-11) \exp (-700 / T)$ & 22 \\
\hline $\mathrm{Cl}_{2} \mathrm{O}+\mathrm{OH} \rightarrow \mathrm{HOCl}+\mathrm{ClO}$ & $6.50(-12)$ & 22 \\
\hline $\mathrm{CCl}_{2}+\mathrm{O}_{2} \rightarrow \mathrm{COCl}+\mathrm{ClO}$ & $1.66(-11) \exp (-505 / T)$ & $19^{c}$ \\
\hline $\mathrm{CCl}_{4}+\mathrm{O} \rightarrow \mathrm{CCl}_{3}+\mathrm{ClO}$ & $4.98(-13) \exp (-2200 / T)$ & 22 \\
\hline $\mathrm{CCl}_{4}+\mathrm{O}\left({ }^{1} \mathrm{D}\right) \rightarrow \mathrm{CCl}_{3}+\mathrm{ClO}$ & $3.54(-10)$ & 23 \\
\hline $\mathrm{C}_{2} \mathrm{Cl}_{3}+\mathrm{O}_{2} \rightarrow \mathrm{C}_{2} \mathrm{Cl}_{2} \mathrm{O}+\mathrm{ClO}$ & $5.25(-13) \exp (-2525 / T)$ & 19 \\
\hline $\mathrm{C}_{2} \mathrm{HCl}_{4}+\mathrm{O}_{2} \rightarrow \mathrm{CHCl}_{2} \mathrm{COCl}+\mathrm{ClO}$ & $1.66(-11) \exp (-2525 / T)$ & 19 \\
\hline $\mathrm{HOCl}+\mathrm{O} \rightarrow \mathrm{OH}+\mathrm{ClO}$ & $1.00(-11) \exp (-2200 / T)$ & 22 \\
\hline $\mathrm{HOCl}+\mathrm{OH} \rightarrow \mathrm{H}_{2} \mathrm{O}+\mathrm{ClO}$ & $3.00(-12) \exp (-500 / T)$ & 22 \\
\hline $\mathrm{ClOO}+\mathrm{H} \rightarrow \mathrm{OH}+\mathrm{ClO}$ & $5.64(-11)$ & 22 \\
\hline $\mathrm{ClOO}+\mathrm{O} \rightarrow \mathrm{O}_{2}+\mathrm{ClO}$ & $5.25(-11) \exp (-252.2)$ & 19 \\
\hline $\mathrm{COCl}+\mathrm{O}_{2} \rightarrow \mathrm{CO}_{2}+\mathrm{ClO}$ & $1.00(-13)$ & $19^{c}$ \\
\hline $\mathrm{COCl}+\mathrm{O} \rightarrow \mathrm{CO}+\mathrm{ClO}$ & $1.66(-10)$ & $19^{c}$ \\
\hline \multicolumn{3}{|c|}{ Additional reactions with and producing $\mathrm{COCl}$} \\
\hline $\mathrm{COCl}+\mathrm{Cl} \rightarrow \mathrm{CO}+\mathrm{Cl}_{2}$ & $2.16(-9) \exp (-1670 / T)$ & 22 \\
\hline $\mathrm{COCl}+\mathrm{M} \rightarrow \mathrm{CO}+\mathrm{Cl}+\mathrm{M}$ & $3.31(-10) \exp (-3283 / T)$ & 19 \\
\hline $\mathrm{COCl}+\mathrm{H} \rightarrow \mathrm{CO}+\mathrm{HCl}$ & $1.66(-10)$ & 19 \\
\hline $\mathrm{COCl}+\mathrm{OH} \rightarrow \mathrm{CO}+\mathrm{HOCl}$ & $1.66(-10)$ & 19 \\
\hline $\mathrm{COCl}+\mathrm{O} \rightarrow \mathrm{CO}_{2}+\mathrm{Cl}$ & $1.66(-11)$ & 19 \\
\hline $\mathrm{CCl}+\mathrm{O} \rightarrow \mathrm{COCl}$ & $1.00(-12)$ & c \\
\hline $\mathrm{CCl}+\mathrm{O}_{2} \rightarrow \mathrm{O}+\mathrm{COCl}$ & $2.90(-12)$ & $22^{e}$ \\
\hline
\end{tabular}




\begin{tabular}{|c|c|c|}
\hline Process & Rate coefficient ${ }^{b}$ & Ref. \\
\hline $\mathrm{CCl}_{2}+\mathrm{O} \rightarrow \mathrm{Cl}+\mathrm{COCl}$ & $1.00(-11)$ & $\mathrm{c}$ \\
\hline $\mathrm{CCl}_{2}+\mathrm{OH} \rightarrow \mathrm{HCl}+\mathrm{COCl}$ & $1.00(-11)$ & c \\
\hline $\mathrm{C}_{2} \mathrm{Cl}+\mathrm{O}_{2} \rightarrow \mathrm{CO}+\mathrm{COCl}$ & $1.66(-11) \exp (-2525 / T)$ & 19 \\
\hline $\mathrm{C}_{2} \mathrm{Cl}_{2}+\mathrm{O}_{2} \rightarrow \mathrm{COCl}+\mathrm{COCl}$ & $1.66(-13) \exp (-2525 / T)$ & 19 \\
\hline $\mathrm{C}_{2} \mathrm{HCl}_{2}+\mathrm{O}_{2} \rightarrow \mathrm{CHOCl}+\mathrm{COCl}$ & $1.66(-13) \exp (-2525 / T)$ & 19 \\
\hline $\mathrm{CHCl}+\mathrm{O}_{2} \rightarrow \mathrm{OH}+\mathrm{COCl}$ & $1.66(-11) \exp (-505 / T)$ & 19 \\
\hline $\mathrm{CHOCl}+\mathrm{Cl} \rightarrow \mathrm{HCl}+\mathrm{COCl}$ & $3.31(-11) \exp (-1515 / T)$ & 19 \\
\hline $\mathrm{CHOCl}+\mathrm{O} \rightarrow \mathrm{OH}+\mathrm{COCl}$ & $5.00(-13)$ & $\mathrm{c}$ \\
\hline \multicolumn{3}{|l|}{ Additional reactions with $\mathrm{C}_{n} \mathrm{Cl}_{x}$} \\
\hline $\mathrm{CCl}_{4}+\mathrm{OH} \rightarrow \mathrm{HOCl}+\mathrm{CCl}_{3}$ & $1.00(-12) \exp (-2320 / T)$ & 22 \\
\hline $\mathrm{CCl}_{3}+\mathrm{Cl} \rightarrow \mathrm{CCl}_{4}$ & $5.00(-11)$ & 22 \\
\hline $\mathrm{CCl}_{3}+\mathrm{Cl}_{2} \rightarrow \mathrm{CCl}_{4}+\mathrm{Cl}$ & $4.17(-12) \exp (-3030 / T)$ & 19 \\
\hline $\mathrm{CCl}_{3}+\mathrm{O}_{2}+\mathrm{M} \rightarrow \mathrm{CCl}_{3} \mathrm{O}_{2}+\mathrm{M}$ & $3.24(-23) T^{-3} \mathrm{~cm}^{6} \mathrm{~s}^{-1}$ & $22^{2}$ \\
\hline $\mathrm{CCl}_{3}+\mathrm{O}_{3} \rightarrow \mathrm{CCl}_{3} \mathrm{O}+\mathrm{O}_{2}$ & $5.00(-13)$ & c \\
\hline $\mathrm{CCl}_{3}+\mathrm{CCl}_{3} \rightarrow \mathrm{C}_{2} \mathrm{Cl}_{6}$ & $2.35(12) T^{-7.48} \exp (-3384 / T)$ & 19 \\
\hline $\mathrm{CCl}_{3}+\mathrm{CCl}_{3} \rightarrow \mathrm{C}_{2} \mathrm{Cl}_{4}+\mathrm{Cl}_{2}$ & $3.72(2) T^{-4.43} \exp (-4545 / T)$ & 19 \\
\hline $\mathrm{CCl}_{3}+\mathrm{CHCl}_{2} \rightarrow \mathrm{C}_{2} \mathrm{HCl}_{5}$ & $2.76(10) T^{-6 \cdot 79} \exp (-3030 / T)$ & 19 \\
\hline $\mathrm{CCl}_{3}+\mathrm{CHCl}_{2} \rightarrow \mathrm{C}_{2} \mathrm{Cl}_{4}+\mathrm{HCl}$ & $3.89(-4) T^{-2 \cdot 45} \exp (-3232 / T)$ & 19 \\
\hline $\mathrm{CCl}_{3}+\mathrm{C}_{2} \mathrm{Cl}_{2} \rightarrow \mathrm{C}_{3} \mathrm{Cl}_{5}$ & $5.25(-13) \exp (-2677 / T)$ & 19 \\
\hline $\mathrm{CCl}_{3}+\mathrm{C}_{2} \mathrm{Cl}_{4} \rightarrow \mathrm{C}_{3} \mathrm{Cl}_{7}$ & $5.25(-13) \exp (-2172 / T)$ & 19 \\
\hline $\mathrm{CCl}_{3}+\mathrm{CCl}_{3} \mathrm{O}_{2} \rightarrow \mathrm{CCl}_{3} \mathrm{O}+\mathrm{CCl}_{3} \mathrm{O}$ & $1.00(-12)$ & 22 \\
\hline $\mathrm{CCl}_{2}+\mathrm{Cl} \rightarrow \mathrm{CCl}_{3}$ & $5.00(-11)$ & c \\
\hline $\mathrm{CCl}_{2}+\mathrm{Cl}_{2} \rightarrow \mathrm{CCl}_{3}+\mathrm{Cl}$ & $8.33(-12) \exp (-1515 / T)$ & 19 \\
\hline $\mathrm{Cl}+\mathrm{H}_{2} \rightarrow \mathrm{HCl}+\mathrm{H}$ & $3.70(-11) \exp (-2300 / T)$ & 22 \\
\hline $\mathrm{Cl}+\mathrm{O}_{2}+\mathrm{M} \rightarrow \mathrm{ClOO}+\mathrm{M}$ & $9.00(-30) T^{-1.45} \mathrm{~cm}^{6} \mathrm{~s}^{-1}$ & 22 \\
\hline $\mathrm{Cl}+\mathrm{OH} \rightarrow \mathrm{O}+\mathrm{HCl}$ & $9.80(-12) \exp (-2860 / T)$ & 22 \\
\hline $\mathrm{Cl}+\mathrm{ClOO} \rightarrow \mathrm{Cl}_{2}+\mathrm{O}_{2}$ & $1.40(-10)$ & 22 \\
\hline $\mathrm{Cl}+\mathrm{HO}_{2} \rightarrow \mathrm{HCl}+\mathrm{O}_{2}$ & $3.00(-11)$ & 23 \\
\hline $\mathrm{Cl}+\mathrm{CHCl}_{3} \rightarrow \mathrm{CCl}_{3}+\mathrm{HCl}$ & $1.15(-11) \exp (-1667 / T)$ & 19 \\
\hline $\mathrm{Cl}+\mathrm{HOCl} \rightarrow \mathrm{Cl}_{2}+\mathrm{OH}$ & $3.00(-12) \exp (-130 / T)$ & 22 \\
\hline $\mathrm{Cl}+\mathrm{H}_{2} \mathrm{O}_{2} \rightarrow \mathrm{HO}_{2}+\mathrm{HCl}$ & $3.32(-12) \exp (-1010 / T)$ & $22^{\mathrm{c}}$ \\
\hline \multicolumn{3}{|l|}{ Miscellaneous reactions } \\
\hline $\mathrm{HCl}+\mathrm{O} \rightarrow \mathrm{OH}+\mathrm{Cl}$ & $9.78(-12) \exp (-3308 / T)$ & 22 \\
\hline $\mathrm{HCl}+\mathrm{OH} \rightarrow \mathrm{H}_{2} \mathrm{O}+\mathrm{Cl}$ & $3.00(-12) \exp (-415 / T)$ & 22 \\
\hline $\mathrm{HCl}+\mathrm{H} \rightarrow \mathrm{H}_{2}+\mathrm{Cl}$ & $1.32(-11) \exp (-1710 / T)$ & 22 \\
\hline $\mathrm{HOCl}+\mathrm{H} \rightarrow \mathrm{HCl}+\mathrm{OH}$ & $1.66(-11) \exp (-505 / T)$ & 19 \\
\hline $\mathrm{CHCl}_{3}+\mathrm{O} \rightarrow \mathrm{OHI}+\mathrm{CCl}_{3}$ & $4.98(-12) \exp (-2500 / T)$ & 22 \\
\hline $\mathrm{CHCl}_{3}+\mathrm{OH} \rightarrow \mathrm{H}_{2} \mathrm{O}+\mathrm{CCl}_{3}$ & $4.06(-12) \exp (-1088 / T)$ & 22 \\
\hline $\mathrm{ClOO}+\mathrm{M} \rightarrow \mathrm{Cl}+\mathrm{O}_{2}+\mathrm{M}$ & $1.50(-8) \exp (-3286 / T)$ & 22 \\
\hline
\end{tabular}

${ }^{a}$ This table lists a subset of the reactions used in the model which directly pertain to $\mathrm{C}_{2} \mathrm{HCl}_{3}$ remediation. A complete list of reactions and rate coefficients used in the model can be requested from the authors.

${ }^{6}$ Rate coefficients have units of $\mathrm{cm}^{3} \mathrm{~s}^{-1}$ unless otherwise noted. $T$ is the gas temperature (K). Activation energies are given in $\mathrm{K}$. $3(10)$ denotes $3 \times 10^{10}$. "Rate coefficient was estimated.

${ }^{\mathrm{d}}$ Rate coefficient was estimated. See text for discussion.

'Products were estimated.

on the modeling of Chang and Senkan ${ }^{19,20}$ who investigated the high temperature combustion of fuel rich $\mathrm{C}_{2} \mathrm{HCl}_{3} / \mathrm{O}_{2} / \mathrm{Ar}$ flames. We included their full reaction scheme, however the reactions listed in Table I are only a pertinent subset which are important for our conditions. A full listing of species and reactions and rate coefficients can be obtained by request from the authors.

The plasma in a dielectric barrier discharge consists of filamentary streamers and arcs. The dynamics of microstreamers in high pressure plasmas have been addressed by the authors and others in the context of corona discharges, ${ }^{1}$ instabilities in $\mathrm{KrF}$ lasers, ${ }^{21}$ and dielectric barrier discharges. ${ }^{14}$ In this work, we have not attempted to resolve those dynamics, but have instead chosen to emphasize the plasma chemistry. We simulate only the volume averaged species densities. Successive discharge pulses are simulated in the following fashion. The kinetics and circuit models are run for a single discharge pulse. The species densities are allowed to evolve after the discharge pulse, and then those evolved densities are used as initial conditions for the next discharge pulse. In this fashion, every volume of gas is processed during every discharge pulse when, in reality, a given volume of gas is processed during only a small fraction of the discharge pulses.

We used a repetition rate of $1 \mathrm{kHz}$ in the model, slightly higher than in the experiment. The results, however, are not particularly sensitive to repetition rate, being primarily only a a function of energy deposition. The duration of a single current pulse is typically $10-25 \mathrm{~ns}$, and is determined by the voltage and capacitance of the dielectric in series with the microarc. We chose these values to produce selected specific energy deposition per pulse. 


\section{REACTION MECHANISMS}

The reaction chemistry in high temperature combustion of TCE is initiated by heterogeneous pyrolysis of $\mathrm{C}_{2} \mathrm{HCl}_{3}$, which is followed by hydrogen abstraction by the liberated $\mathrm{Cl}$ atom. The important reactions are

$$
\mathrm{C}_{2} \mathrm{HCl}_{3}+\mathrm{M} \rightarrow \mathrm{C}_{2} \mathrm{HCl}_{2}+\mathrm{Cl}+\mathrm{M}, \quad \Delta E=70 \mathrm{kcal} / \mathrm{mol},
$$

$\mathrm{C}_{2} \mathrm{HCl}_{3}+\mathrm{Cl} \rightarrow \mathrm{C}_{2} \mathrm{Cl}_{3}+\mathrm{HCl}, \quad \Delta E=3.5 \mathrm{kcal} / \mathrm{mol}$

$\mathrm{C}_{2} \mathrm{Cl}_{3}+\mathrm{O}_{2} \rightarrow \mathrm{COCl}_{2}+\mathrm{COCl}, \Delta E=5 \mathrm{kcal} / \mathrm{mol}$,

$\mathrm{COCl}_{2}+\mathrm{Cl} \rightarrow \mathrm{COCl}+\mathrm{Cl}_{2}, \quad \Delta E=20 \mathrm{kcal} / \mathrm{mol}$,

$\mathrm{COCl}+\mathrm{M} \rightarrow \mathrm{CO}+\mathrm{Cl}+\mathrm{M}, \quad \Delta E=15 \mathrm{kcal} / \mathrm{mol}$,

where $\Delta E$ is the activation energy for the reaction. The intermediate $\mathrm{C}_{2} \mathrm{Cl}_{3}$ rapidly reacts with $\mathrm{O}_{2}$ to form $\mathrm{COCl}_{2}$ and $\mathrm{COCl} . \mathrm{COCl}_{2}$ reacts with $\mathrm{Cl}$ to form $\mathrm{COCl}$, which undergoes heterogeneous pyrolysis to $\mathrm{CO}+\mathrm{Cl}$. The conversion of TCE to products is a chain reaction propagated by $\mathrm{Cl}$. The initiating reaction has an activation energy of 70 $\mathrm{kcal} / \mathrm{mol}$, while the destruction channels for the products $\mathrm{COCl}_{2}$ and $\mathrm{COCl}$ have activation energies of 20 and 15 $\mathrm{kcal} / \mathrm{mol}$, respectively. In partially ionized plasmas, where the heavy particle temperature is near $300 \mathrm{~K}$, these destruction mechanisms are of little or no importance.

In low temperature plasmas sustained in $\mathrm{Ar} / \mathrm{O}_{2} / \mathrm{H}_{2} \mathrm{O}$ mixtures, electron impact dissociation produces a variety of products, including excited states and ions of Ar. Excitation transfer from $\mathrm{Ar}^{*}$ and $\mathrm{Ar}^{+}$to $\mathrm{O}_{2}$ and $\mathrm{H}_{2} \mathrm{O}$, and dissociative recombination of $\mathrm{O}_{2}^{+}$and $\mathrm{H}_{2} \mathrm{O}^{+}$ultimately produce $\mathrm{O}\left({ }^{3} \mathrm{P}\right), \mathrm{O}\left({ }^{1} D\right), \mathrm{O}_{2}\left({ }^{1} \Delta\right), \mathrm{H}$ and $\mathrm{OH}$ as the activated species. In dry $\mathrm{Ar} / \mathrm{O}_{2}$ mixtures at low gas temperatures, the dominant reactions for remediating TCE are

$$
\begin{aligned}
& \mathrm{C}_{2} \mathrm{HCl}_{3}+\mathrm{O} \rightarrow \mathrm{CHOCl}+\mathrm{CCl}_{2}, \\
& \mathrm{CCl}_{2}+\mathrm{O}_{2} \rightarrow \mathrm{ClO}+\mathrm{COCl}, \\
& \mathrm{CHOCl}+\left\{\begin{array}{l}
\mathrm{O} \\
\mathrm{Cl}
\end{array}\right\} \rightarrow \mathrm{COCl}+\left\{\begin{array}{l}
\mathrm{OH} \\
\mathrm{HCl}
\end{array}\right\}, \\
& \mathrm{CHOCl}+\left\{\begin{array}{l}
\mathrm{O} \\
\mathrm{Cl}
\end{array}\right\} \rightarrow \mathrm{CO}+\left\{\begin{array}{l}
\mathrm{ClO} \\
\mathrm{Cl}_{2}
\end{array}\right\}, \\
& \mathrm{COCl}+\mathrm{O}_{2} \rightarrow \mathrm{CO}_{2}+\mathrm{ClO} .
\end{aligned}
$$

The reaction mechanism is schematically shown in Fig. 3. The $\mathrm{ClO}$ radical is an important intermediate. It rapidly back-rcacts with TCE to form phosgene and methyldichloride, which in turns rapidly reacts with oxygen

$$
\begin{aligned}
& \mathrm{C}_{2} \mathrm{HCl}_{3}+\mathrm{ClO} \rightarrow \mathrm{COCl}_{2}+\mathrm{CHCl}_{2}, \\
& \mathrm{CHCl}_{2}+\mathrm{O} \rightarrow \mathrm{CHOCl}+\mathrm{Cl} .
\end{aligned}
$$

These reaction pathways lead towards $\mathrm{CO}, \mathrm{CO}_{2}, \mathrm{HCl}$, and $\mathrm{COCl}_{2}$ as terminal species. At low temperatures, $\mathrm{CO}$ and $\mathrm{COCl}_{2}$ are fairly stable molecules. The activation energy for heterogeneous pyrolysis of $\mathrm{COCl}_{2}$ is $50 \mathrm{kcal} / \mathrm{mol}$, while

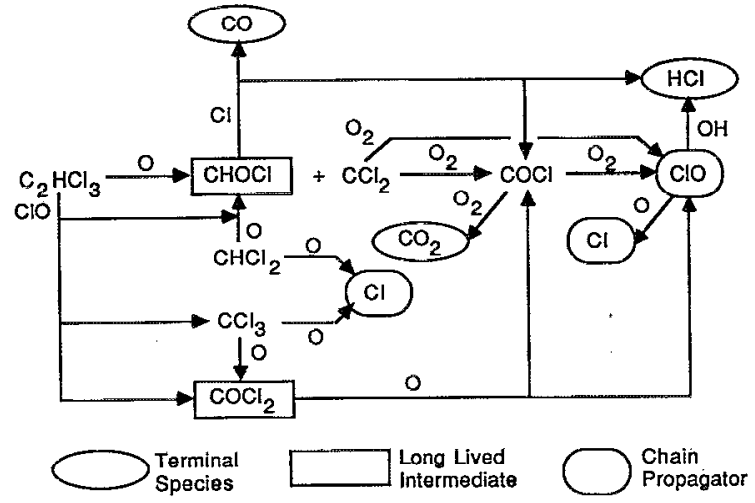

FIG. 3. Diagram of the dominant reaction pathways in plasma remediation of TCE. The $\mathrm{O}$ atoms and $\mathrm{OH}$ radicals are produced by electron impact dissociation of $\mathrm{O}_{2}$ and $\mathrm{H}_{2} \mathrm{O}$.

its activation energy for reaction with $\mathrm{Cl}$ is $20 \mathrm{kcal} / \mathrm{mol}$. Its only effective means of destruction, other than by electron impact, is a slow reaction with oxygen atoms

$$
\mathrm{COCl}_{2}+\mathrm{O}\left({ }^{3} \mathrm{P}\right) \rightarrow \mathrm{COCl}+\mathrm{ClO} \text {. }
$$

The rate coefficient for this process is $1 \times 10^{-14} \mathrm{~cm}^{3} \mathrm{~s}^{-1}$. The process mostly likely proceeds at a gas kinetic rates for reactions with $O\left({ }^{1} D\right)$.

In wet mixtures, $\mathrm{OH}$ radicals are produced by electron impact dissociation of $\mathrm{H}_{2} \mathrm{O}$ and excitation transfer from excited states of Ar. The reaction pathways which become available in wet mixtures are

$$
\begin{aligned}
& \mathrm{C}_{2} \mathrm{HCl}_{3}+\mathrm{OH} \rightarrow \mathrm{C}_{2} \mathrm{Cl}_{3}+\mathrm{H}_{2} \mathrm{O}, \\
& \mathrm{ClO}+\mathrm{OH} \rightarrow \mathrm{HCl}+\mathrm{O}_{2}, \\
& \mathrm{COCl}_{2}+\mathrm{OH} \rightarrow \mathrm{COCl}+\mathrm{HOCl} .
\end{aligned}
$$

TCE reacts with hydroxyl radicals, however the rate coefficient is no larger than that with $O$ atoms. Therefore in mixtures having low humidity, the rate of initial destruction of TCE is not necessarily enhanced by the presence of $\mathrm{OH}$ radicals. The additional reaction pathway for $\mathrm{COCl}_{2}$ with $\mathrm{OH}$ is not particularly effective due to its moderate activation energy of $10 \mathrm{kcal} / \mathrm{mol}$. The reaction of $\mathrm{ClO}$ with $\mathrm{OH}$ ultimately reduces the production of $\mathrm{COCl}_{2}$ since $\mathrm{ClO}$ is prevented from backreacting with the TCE, however it also reduces the rate of remediation of TCE.

Two additional species can be produced by reaction of $\mathrm{OH}$ with TCE, $\mathrm{CHCl}_{2} \mathrm{COCl}$ and $\mathrm{CHCl}_{2}$. $\mathrm{CHCl}_{2} \mathrm{COCl}$ is moderately stable at low temperatures. It slowly reacts with $\mathrm{Cl}$ and, most likely, $\mathrm{O} . \mathrm{CHCl}_{2}$ also slowly reacts with $\mathrm{O}_{2}$.

\section{DESTRUCTION OF TCE USING SILENT DISCHARGES}

The destruction of TCE using dielectric barrier discharges was investigated using $\mathrm{Ar} / \mathrm{O}_{2}=80 / 20$ and $\mathrm{Ar} / \mathrm{O}_{2} / \mathrm{H}_{2} \mathrm{O}=78 / 20 / 2$ mixtures at $1 \mathrm{~atm}$, and an initial gas temperature of $300 \mathrm{~K}$. The percentage of TCE destroyed as a function of energy deposition $(\mathrm{J} / \mathrm{1})$ is shown in 


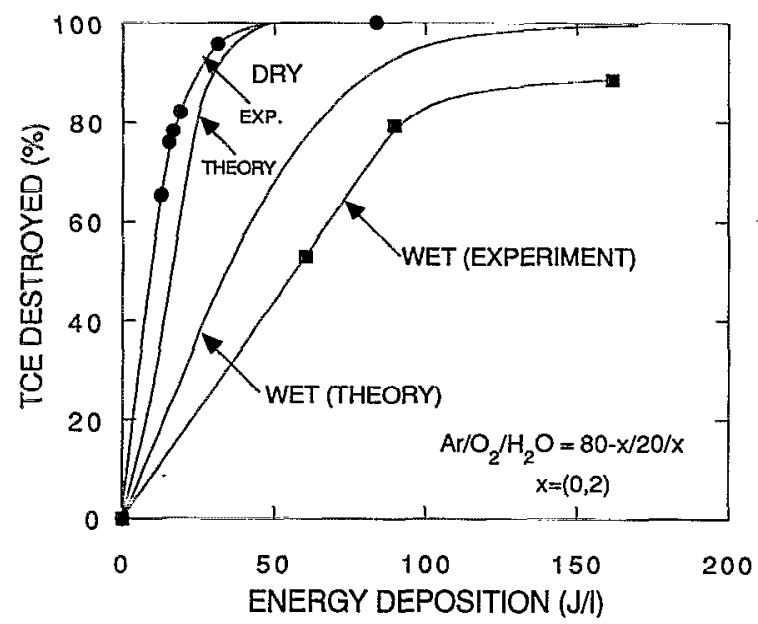

FIG. 4. Experimental and theoretical results for the destruction of 500 ppm TCE in atmospheric pressure gas streams of $\mathrm{Ar} / \mathrm{O}_{2} / \mathrm{H}_{2} \mathrm{O}$ $=80-x / 20 / x ; x=0,2$. The destruction efficiency is smaller using wet mixtures due to the interception of $\mathrm{ClO}$ radicals by $\mathrm{OH}$ radicals.

Fig. 4(a) for an initial concentration of $500 \mathrm{ppm}$. TCE is rapidly and efficiently converted to products in the silent discharge, with $\simeq 90 \%$ of the initial TCE being destroyed with an energy deposition of $25 \mathrm{~J} / 1$. A useful figure of merit is $\eta=[\mathrm{ppm}$ of TCE converted/energy deposition $\left(\mathrm{mJ} / \mathrm{cm}^{3}\right)$ ] which, for the dry mixture, is $\eta \simeq 18$. Conversion of TCE to products in wet mixtures, though, is less efficient, as shown in Fig. 4. In wet mixtures, the figure of merit is $\eta<5$.

Results from the model are also shown in Fig. 4. The theoretical results agree well with the experiments for the dry mixtures, and reproduce the trend of decreasing efficiency with increasing humidity of the mixture. Calculated species densities as a function of time for wet and dry mixtures are shown in Fig. 5(a). The specific energy deposition is $5 \mathrm{~mJ} / \mathrm{cm}^{3} /$ pulsc. Recall that the entire gas mixture is processed on every discharge pulse in the model, and so the time scale shown in the figure does not correspond to the average residence time of gases in the plasma. The pertinent parameter of interest is cummulative specific energy deposition.

In the dry mixture, only a small fraction of TCE is converted to products following each current pulse. The processing occurs in two steps. This is shown in more detail in Fig. 5(b), where densitics are plotted after a single current pulse $\left(10 \mathrm{~mJ} / \mathrm{cm}^{3}\right)$. Oxygen atoms are produced during the short current pulse reaching a density of nearly $10^{16} \mathrm{~cm}^{-3}$. The $\mathrm{O}$ atoms are rapidly converted to products, primarily ozone, during the interpulse period. Only a small fraction of the $O$ atoms ultimately react with TCE and its products due to their moderate activation energies. As the TCE slowly reacts with $\mathrm{O}, \mathrm{ClO}$ is produced which, in turn, reacts with TCE to produce $\mathrm{COCl}_{2}$. The density of $\mathrm{ClO}$ is maximum when the $O$ atoms are just exhausted, and its source is terminated. Since the destruction of $\mathrm{COCl}_{2}$ is very slow, its density integrates during the interpulse period.

The interpulse dynamics of the species densities change
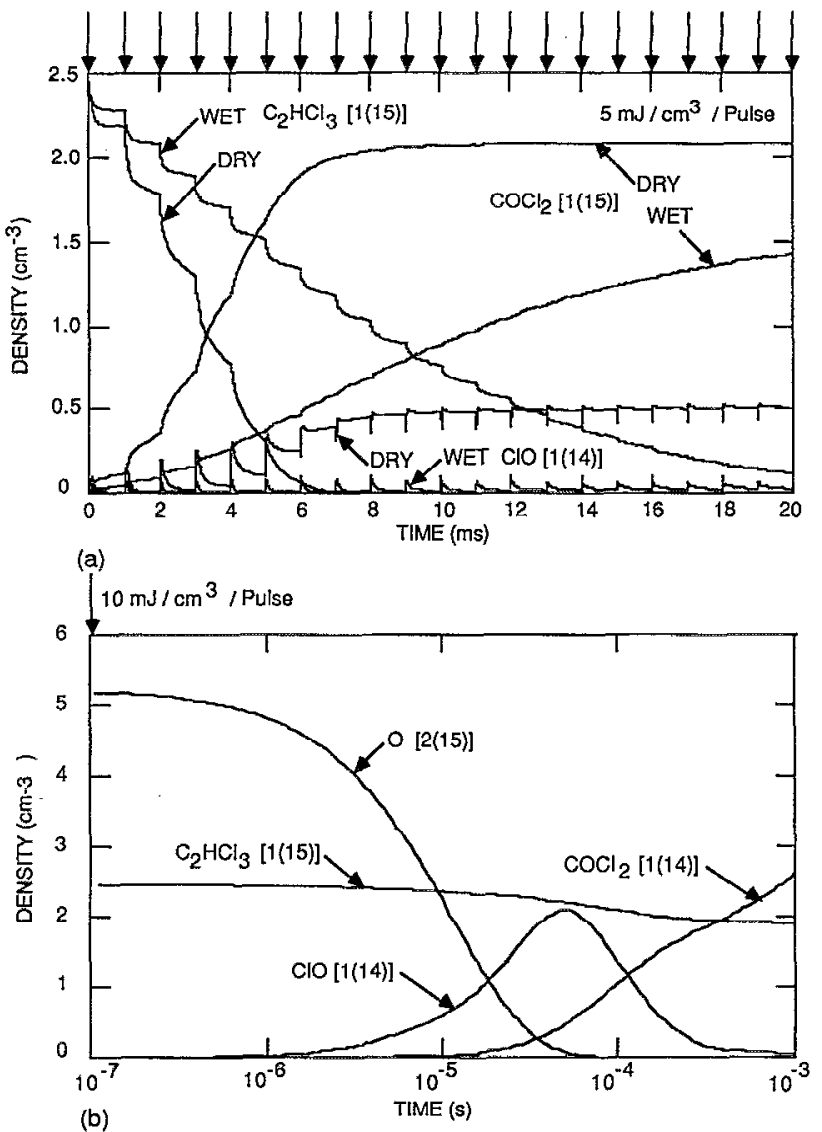

FIG. 5. Calculated species densities during multipulse treatment of TCE in a SDP. The numbers in brackets show the multiplicative factor required to convert the scale to density. The arrows at the top of the figure show the time at which the plasma is pulsed. (a) Species densities for wet and dry mixtures $\left(\mathrm{Ar} / \mathrm{O}_{2} / \mathrm{H}_{2} \mathrm{O}=80-x / 20 / x, x=0,2\right)$. The interception of $\mathrm{ClO}$ by $\mathrm{OH}$ radicals in the wet mixture is shown. (b) Species densities following the first discharge pulse.

as the specific energy deposition increases, TCE is exhausted, and products accumulate. In Fig. 5(a), the density of TCE is shown for a series of twenty $5 \mathrm{~mJ} / \mathrm{cm}^{3}$ pulses. The efficiency of conversion of TCE actually improves with accumulated energy deposition as the density of $\mathrm{ClO}$ increases. $\mathrm{ClO}$ is initially exhausted following each pulse as it back reacts with TCE. However, as other products accumulate in the discharge $\left(\mathrm{Cl}, \mathrm{O}_{3}, \mathrm{Cl}_{2}, \mathrm{CCl}_{4}\right.$, $\mathrm{CHCl}_{2} \mathrm{COCl}$ ), $\mathrm{ClO}$ production increases. For example, $\mathrm{O}_{3}$ increases to densities of $(8-10) \times 10^{16} \mathrm{~cm}^{-3}$, and its reaction with $\mathrm{Cl}$ atoms is an important source of $\mathrm{ClO}$. Due to the low rate of reaction of $\mathrm{COCl}_{2}$ with $\mathrm{O}$ atoms, its density monotonically increases until the TCE is exhausted. Its density then only very slowly decreases, as discussed below.

In wet mixtures, the conversion of TCE should improve because of its additional reactions with $\mathrm{OH}$. We find, however, that the conversion of TCE is less efficient in wet mixtures. This is most likely a consequence of $\mathrm{ClO}$ reacting with $\mathrm{OH}\left(\mathrm{ClO}+\mathrm{OH} \rightarrow \mathrm{HCl}+\mathrm{O}_{2}\right)$ which depletes $\mathrm{ClO}$ and prevents its reacting with TCE. We performed an exhaustive parametric survey of reaction channels destroying 


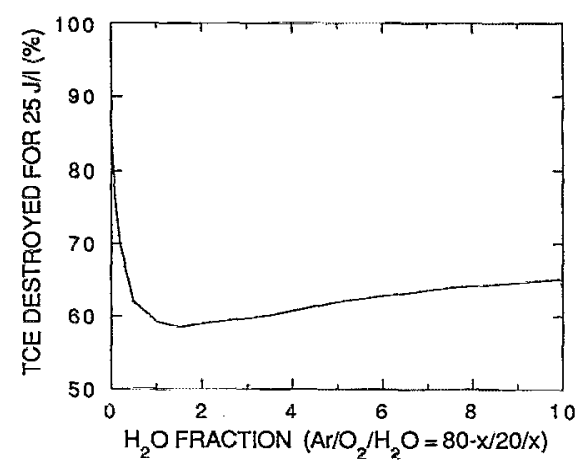

FIG. 6. Calculated results for removal of TCE at an energy deposition of $25 \mathrm{~J} / 1$ as a function of water concentration. The removal efficiency increases at high water concentration due to direction reactions of $\mathrm{OH}$ with TCE.

TCE which are most affected by addition of water. We found that all channels having reasonably large rate coefficients increased the TCE destruction rate except those involving reactions with $\mathrm{ClO}$. The most sensitive process was $\mathrm{ClO}+\mathrm{OH} \rightarrow$ products. We parameterized the rate coefficient for this reaction between the recommended value $2 \times 10^{-11}$ (Ref. 22) to $5 \times 10^{-11} \mathrm{~cm}^{3} \mathrm{~s}^{-1}$ with estimated products of $\mathrm{HCl}+\mathrm{O}_{2}$. The experimental trends of decreasing remuval efficiency with increasing $\mathrm{H}_{2} \mathrm{O}$ are well reproduced by this mechanism. Since $\mathrm{ClO}$ is a major precursor for $\mathrm{COCl}_{2}$, the rate of production of phosgene also decreases. Since the presence of $\mathrm{OH}$ also promotes the production of $\mathrm{HCl}$, a larger fraction of the $\mathrm{Cl}$ is bound in $\mathrm{HCl}$ as final products when using wet mixtures.

The removal efficiency in wet mixtures results from a balance between an improved rate of destruction of TCE by the additional $\mathrm{OH}$ and $\mathrm{H}$ radicals produced, and a reduced rate of destruction due to interception of reaction intermediates. As a result, the removal efficiency may begin to increase when using large fractions of water if TCE removal by $\mathrm{OH}$ dominates over the interception of intermediates. This trend is shown in Fig. 6 where the percentage of TCE removed (at $25 \mathrm{~J} / 1$ ) is plotted as a function of water fraction.

The desired end products for plasma remediation of TCE are $\mathrm{CO}_{2}$ and $\mathrm{HCl}$. The final production of these species requires higher energy deposition than is required to destroy TCE. For example, the densities of $\mathrm{CHOCl}$, $\mathrm{COCl}_{2}, \mathrm{CO}_{2}, \mathrm{CO}$, and $\mathrm{HCl}$ are shown in Fig. 7 for a series of $20 \mathrm{~mJ} / \mathrm{cm}^{3}$ current pulses in a dry mixture. The evolution of these products continues long after the TCE is exhausted. At the end of the 20 pulses $\left(400 \mathrm{~mJ} / \mathrm{cm}^{3}\right)$, the $\mathrm{Cl}$ atoms that were initially bound in TCE were converted to products in the following proportions: $\mathrm{COCl}_{2}, 48.3 \%$; $\mathrm{ClO}, 30.0 \%$; $\mathrm{CHOCl}, 7.2 \% ; \mathrm{Cl}_{2}, 12.0 \%$; and $\mathrm{HCl}, 2.5 \%$. Only traces of $\mathrm{Cl}$ are in other species ( $\mathrm{HOCl}, \mathrm{CCl}_{3} \mathrm{O}_{2}$, $\mathrm{Cl}_{2} \mathrm{O}$ ). The carbon atoms initially bound in TCE were were converted to products in the following proportions: $\mathrm{CO}_{2}, 35.6 \% ; \mathrm{COCl}_{2}, 35.9 \%$; $\mathrm{CO}, 17.8 \%$; and $\mathrm{CHOCl}$, $10.7 \%$.

$\mathrm{CHOCl}$ is a fairly stable product of the reaction of

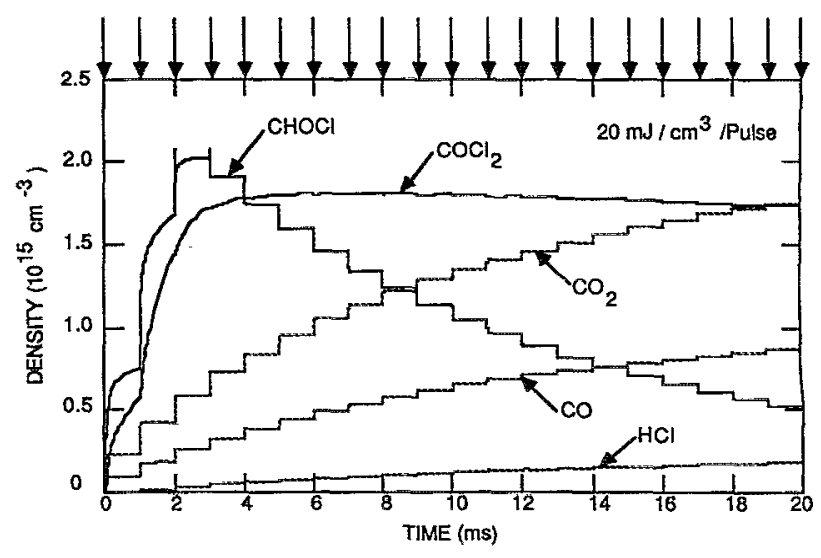

FIG. 7. Intermediate and long lived products for the dry mixture of Fig. 5 as predicted by the model. The source of $\mathrm{CHOCl}$, a direct product of oxidation of TCE, is eliminated when the TCE is exhausted. It is then removed by reactions with $\mathrm{O}$ and $\mathrm{Cl}$.

TCE with $O$ atoms. Its source is depleted when the TCE is fully converted after 3-4 pulses. It therefore slowly decays away by reaction with $\mathrm{Cl}$ and $\mathrm{O}$, ultimately requiring $\simeq 500 \mathrm{~mJ} / \mathrm{cm}^{3}$ for complete remediation. This energy deposition may be an optimistic value since the reaction of $\mathrm{CHOCl}$ with $\mathrm{O}$ atoms is an estimate in our scheme. Although $\mathrm{ClO}$ is produced in large proportions after the TCE is depleted, it will react with itself to produce $\mathrm{ClOO}$, which decays to $\mathrm{Cl}$ and $\mathrm{O}_{2}$. This provides a source of $\mathrm{Cl}$ for scavenging $\mathrm{CHOCl} . \mathrm{COCl}_{2}$ is the most stable product. Its remediation proceeds slowly by reaction with $\mathrm{O}$ atoms.

Experimental measurements of the gas phase density of $\mathrm{COCl}_{2}$ are difficult due to the hydrophilic nature of phosgene. It will be consumed by dissolving in liquid water in any gas mixture in which water aerosols are formed or in which water condenses or coats surfaces. The hydrophilic nature of $\mathrm{COCl}_{2}$ is, in fact, a great benefit to plasma remediation of TCE since any phosgene that is produced is so easily removed from the gas stream by post-treating with a water spray or bubbler. The predictions of $\mathrm{COCl}_{2}$ shown here are, then, worst case values since we have not included reactions of phosgene with water aerosols or any surface reactions.

Experiments were performed to remediate $100 \mathrm{ppm}$ of $\mathrm{COCl}_{2}$ from an $\mathrm{Ar} / \mathrm{O}_{2}$ mixture to determine the energy requirements for $\mathrm{COCl}_{2}$ removal in the absence of TCE. We found that $\approx 6 \mathrm{~J} / \mathrm{cm}^{3}$ were required to destroy this amount of $\mathrm{COCl}_{2}$ by plasma oxidation in dry mixtures. These experiments were simulated with the model, and the results are shown in Fig. 8 for dry and wet mixtures. The model predicts that an energy deposition of $5.4 \mathrm{~J} / \mathrm{cm}^{3}$ $\left[\eta=0.02 \mathrm{ppm} /\left(\mathrm{mJ} / \mathrm{cm}^{3}\right)\right]$ is required to remediate $\mathrm{COCl}_{2}$ in a dry mixture. Slightly less energy is required in a wet mixture in agrcement with the experiments. In the dry mixture, the majority of the $\mathrm{Cl}$ is converted to $\mathrm{ClO}$, which will slowly decay by self reaction. In the wet mixture, the conversion is more directly to $\mathrm{HCl}$.

We also made measurements of the production and survival of $\mathrm{COCl}_{2}$ in TCE mixtures. For example, in a 


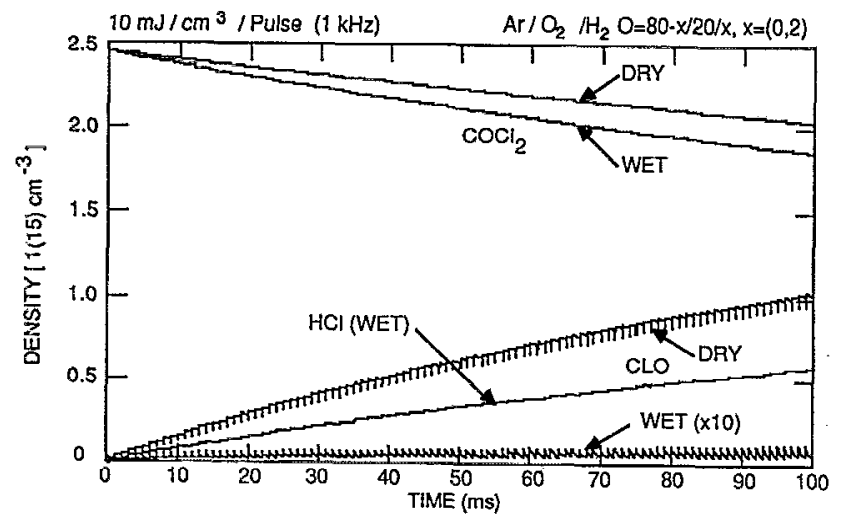

FIG. 8. Predictions for destruction of $100 \mathrm{ppm}$ of $\mathrm{COCl}_{2}$ by plasma oxidation in wet and dry mixtures $\left(\mathrm{Ar} / \mathrm{O}_{2} / \mathrm{H}_{2} \mathrm{O}=80-x / 20 / x, x=0,2\right)$. Experimentally, approximately $6 \mathrm{~J}_{\mathrm{t}} \mathrm{cm}^{-3}$ is required to remove $\mathrm{COCl}_{2}$ from the gas stream using this method. The model predictions are $5.4 \mathrm{~J} / \mathrm{l}$.

typical Ar/ $\mathrm{O}_{2} / \mathrm{TCE}$ mixture with an energy deposition of $0.45 \mathrm{~J} / \mathrm{cm}^{3}, \mathrm{COCl}_{2}$ was detected at $\simeq 15 \mathrm{ppm}$. Results from the model for the same conditions showed $150 \mathrm{ppm}$ of $\mathrm{COCl}_{2}$ after an energy deposition of $0.45 \mathrm{~J} / \mathrm{cm}^{3}$, which is somewhat inconsistent with the results discussed above for the simplier chemistry. Given the long residence time of the gas mixture in the cell $(1.6 \mathrm{~s})$ the discrepancy can be accounted for by a wall destruction reaction having a probability of $\simeq 10^{-3}$.

The efficiency of TCE conversion decreases with increasing energy deposition/pulse. This trend is shown in Fig. 9(a) where the density of TCE is plotted as a function of time for a series of current pulses of 5,10 , and 20 $\mathrm{mJ} / \mathrm{cm}^{3} . \eta$ decreases from $18 \mathrm{ppm} /\left(\mathrm{mJ} / \mathrm{cm}^{3}\right)$ to 10 $\mathrm{ppm} /\left(\mathrm{mJ} / \mathrm{cm}^{3}\right)$ over this range of pulse energies. The peak oxygen atom density after the current pulse increases almost linearly with the energy deposition/pulse. On this basis, the conversion of TCE should simply track the production of $O$ atoms with little change in efficiency. The higher density of $\mathrm{O}$ atoms, though, also increases the rate of depletion of $\mathrm{ClO}\left(\mathrm{ClO}+\mathrm{O} \rightarrow \mathrm{Cl}+\mathrm{O}_{2}\right)$, thereby intercepting its back reaction with TCE. Although the efficiency of TCE conversion is reduced at high specific pulse energy, the production of $\mathrm{COCl}_{2}$ is also reduced, primarly because its production by $\mathrm{ClO}$ reacting with TCE is intercepted. [See Fig. 9(b).]

There are two time scales for remediation of TCE. The short time scale occurs during the first 10 's $\mu \mathrm{s}$ after the current pulse. During this period, the TCE reacts with $O$ atoms formed during the current pulse (see Fig. 10). $\mathrm{CCl}_{2}$ generated by this process quickly reacts with $\mathrm{O}_{2}$. The cyclic production of $\mathrm{ClO}$ continues during the interpulse period and remediates TCE on longer time scales. This long term remediation of TCE by $\mathrm{ClO}$ affects the dependence of the removal efficiency on repetition rate. If the $\mathrm{ClO}$ is not allowed to fully react with the remaining TCE during the interpulse period, it will be consumed by the large $O$ atom density produced during the next pulse, and the conversion efficiency will decrease. The dependence of removal efficiency on repetition rate is shown in Fig. 11 where the

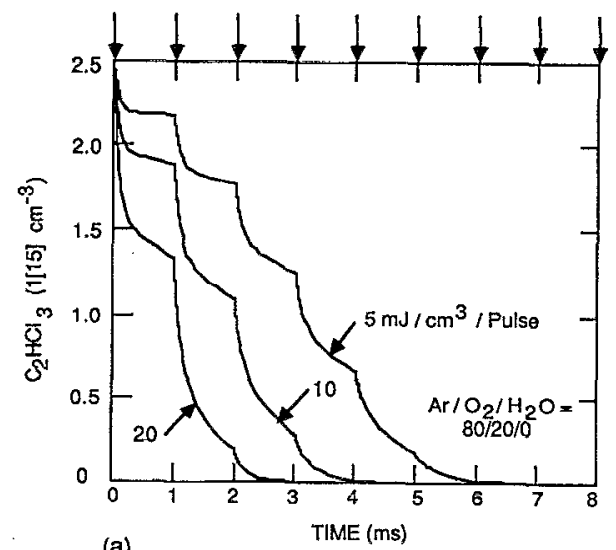

(a)

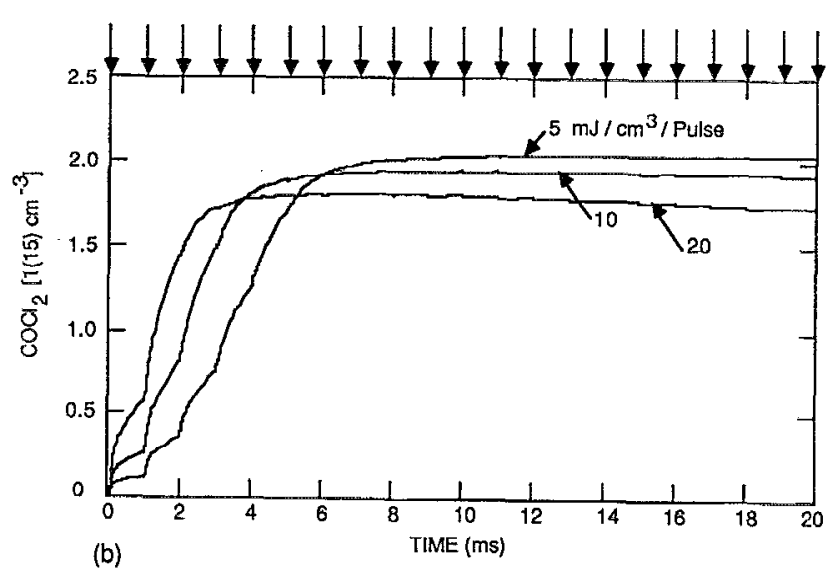

FIG. 9. Model results for plasma remediation of TCE at different discharge powers in a dry mixture. The power was controlled by changing the energy/pulse at constant repetition rate $(1 \mathrm{kHz})$. (a) TCE density, (b) $\mathrm{COCl}_{2}$ density. The efficiency of TCE removal decreases with increasing power deposition while the production of $\mathrm{COCl}_{2}$ decreases.

density of TCE is plotted for a series of current pulses at 1 $\mathrm{kHz}, 500,250$, and $167 \mathrm{~Hz}$. The figure of merit for these examples varies from $\eta=12 \mathrm{ppm} /\left(\mathrm{mJ} / \mathrm{cm}^{3}\right)$ at the high repetition rate to $\eta=17 \mathrm{ppm} /\left(\mathrm{mJ} / \mathrm{cm}^{3}\right)$ at the low repetition rate. The increase in efficiency at the lower repetition rate (lower power deposition) results from a slow removal of TCE by reaction of $\mathrm{ClO}$ and $\mathrm{Cl}$ long after the current pulse is over.

\section{CONCLUDING REMARKS}

The remediation of trichloroethylene in silent discharge plasmas has been experimentally and theoretically investigated. We found that TCE is efficiently removed from $\mathrm{Ar} / \mathrm{O}_{2}$ mixtures, having a figure of merit of $15-20$ $\mathrm{ppm} /\left(\mathrm{mJ} / \mathrm{cm}^{3}\right) . \mathrm{ClO}$ is an important intermediate in the reaction chemistry, as it is ultimately responsible for a large proportion of the TCE removal. The decrease in removal efficiency measured in wet mixtures can be attributed to the interception of $\mathrm{ClO}$ by $\mathrm{OH}$ radicals. The removal efficiency may increase using large fractions of water when reactions of OH radicals with TCE dominate over the removal of reactive intermediates. With moderate en- 


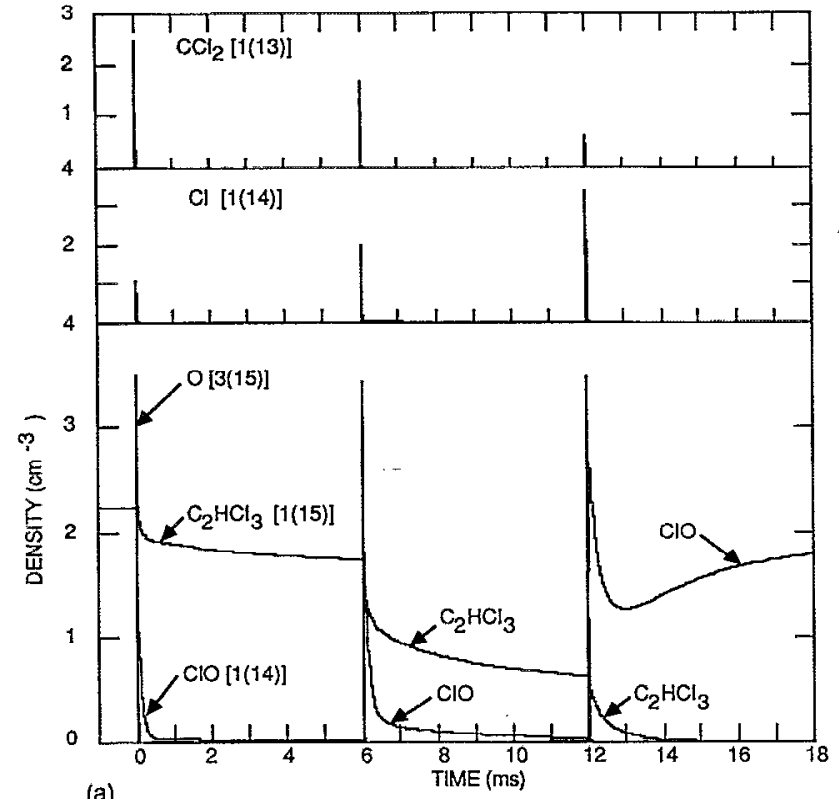

(a)

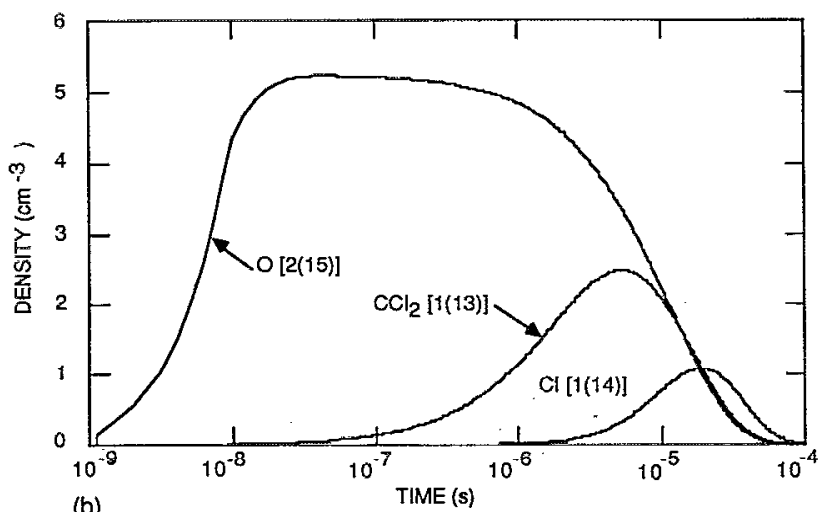

(b)

FIG. 10. The treatment of TCE occurs over both short and long time scales. (a) Model predictions for species densities over long time scales during which TCE is dominantly removed by reaction with $\mathrm{ClO}$. (b) Species densities on short time scales during which TCE dominantly reacts with $\mathrm{O}$ atoms. $\mathrm{CCl}_{2}$ and $\mathrm{Cl}$ rapidly react with $\mathrm{O}_{2}$ on 10 's $\mu \mathrm{s}$ time scale.

ergy deposition (10's $\mathrm{mJ} / \mathrm{cm}^{3}$ ) much of the $\mathrm{Cl}$ from TCE is converted to $\mathrm{COCl}_{2}$ and $\mathrm{HCl}$.

Another convenient figure of merit is $\mathrm{kW} \mathrm{h} \mathrm{kg}{ }^{-1}$, which provides a measure of the electrical energy required to convert TCE to products. Energy requirements of 25 $\mathrm{mJ} / \mathrm{cm}^{3}$ for conversion of $500 \mathrm{ppm}$ of TCE corresponds to $\simeq 2.6 \mathrm{~kW} \mathrm{~h} \mathrm{~kg}^{-1}$. Estimating an electrical efficiency of $30 \%$ for the SDP cell and electrical costs of $\$ 0.10 / \mathrm{kW} \mathrm{h}$, the operating cost of remediating TCE is less than a dollar/ kg.

A legitimate concern in any remediation technique is treatment of the products of the remediation. The dominant direct products of plasma remediation of TCE which contain $\mathrm{Cl}$ are $\mathrm{COCl}_{2}, \mathrm{HCl}$, and $\mathrm{Cl}_{2}$. Large amounts of energy deposition $\left(5-10 \mathrm{~J} / \mathrm{cm}^{3}\right)$ are required to convert $\mathrm{COCl}_{2}$ to products $\left(\mathrm{Cl}_{2}, \mathrm{CO}\right.$, and $\mathrm{CO}_{2}$ in dry mixtures; $\mathrm{HCl}, \mathrm{Cl}_{2}, \mathrm{CO}$, and $\mathrm{CO}_{2}$ in wet mixtures) using the plasma

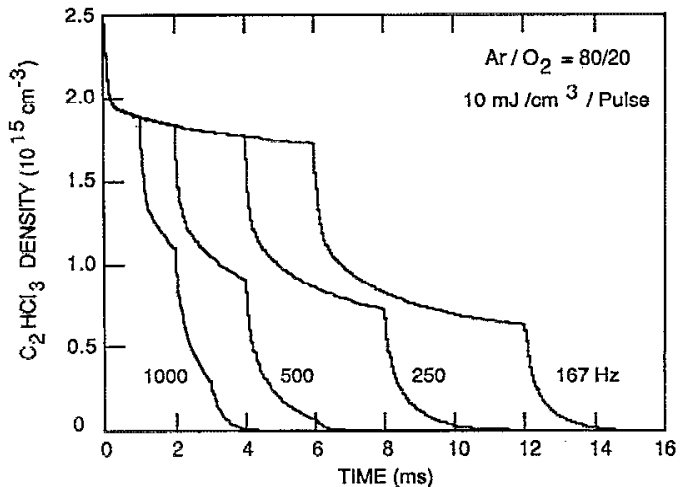

FIG. 11. Destruction of TCE for various repetition frequencies as predicted by the model. Lower repetition frequencies are somewhat more efficient due to long time scale removal processes.

itself. The less energy intensive method of treating the $\mathrm{COCl}_{2}$ is to process the gas stream through a water bubbler or water spray. This process will rapidly dissolve the $\mathrm{COCl}_{2}$ as $\mathrm{HCl}$. The $\mathrm{HCl}$ can be recovered as a recyclable end product, or be safely disposed of using conventional techniques.

\section{ACKNOWLEDGMENTS}

This work was supported by Los Alamos National Laboratory and the National Science Foundation (CTS9113215 and ECS91-02326).

${ }^{1}$ I. Gallinberti, Pure Appl. Chem. 60, 663 (1998).

${ }^{2}$ S. Masuda, Pure Appl. Chem. 60, 727 (1988).

${ }^{3}$ K. Kawamura and V. H. Sui, Radiat. Phys. Chem. 24, 117 (1984).

${ }^{4}$ M. B. Chang, M. J. Kushner, and M. J. Rood, Plasma Chern. Plasma Proc. 12, 565 (1992).

${ }^{5}$ S. Masuda and H. Nakao, IEEE Trans. Ind. Appl. 26, 374 (1990).

${ }^{6}$ I. Sardja and S. K. Dahli, Appl. Phys. Lett. 56, 21 (1990).

${ }^{7}$ J. C. Pearson and D. O. Ham, Radiat. Phys. Chem. 31, 1 (1988).

${ }^{8}$ J. W. Bozzelli and R. B. Barat, Plasma Chem. Plasma Proc. 8, 293 (1988).

${ }^{9}$ L. Bromberg, D. R. Cohn, M. Koch, R. M. Patrick, and P. Thomas, Phys. Lett. A 173, 293 (1993).

${ }^{10}$ W. C. Neely, Proceedings of the 1984 Scientific Conference on Chemical Defense Research, U.S. Army CRDEC-SP-85006.

${ }^{11}$ D. G. Storch and M. J. Kushner, J. Appl. Phys. 73, 51 (1993).

${ }^{12}$ B. Eliasson, M. Hirth, and U. Kogelschatz, J. Phys. D 20, 1421 (1987).

${ }^{13}$ B. Eliasson and U. Kogelschatz, Appl. Phys. B 46, 299 (1988).

${ }^{14}$ B. Eliasson and U. Kogelschatz, IEEE Trans. Plasma Sci. 19, 309 (1991).

${ }^{15}$ L. A. Rosocha, G. K. Anderson, L. A. Bechtold, J. J. Coogan, H. G. Heck, M. Kang, W. H. McCulla, R. A. Tennant, and P. J. Wantuck, in Proceedings of the NATO Advanced Research Workshop on NonThermal Plasma Techniques for Pollution Control (Springer, Berlin, 1993).

${ }^{16}$ M. B. Chang, J. H. Balbach, M. J. Rood, and M. J. Kushner, J. Appl. Phys. 69, 4409 (1991).

${ }^{17}$ J. H. Balbach; MS thesis, University of Illinois, 1990.

${ }^{18}$ F. Kannari, M. Obara, and T. Fujioka, J. Appl. Phys. 57, 4309 (1985).

${ }^{19}$ W.-D. Chang and S. M. Senkan, Environ. Sci. Technol. 23, 442 (1989).

${ }^{20}$ W.-D. Chang, S. B. Karra, and S. M. Senkan, Combust. Sci. Technol. 49, 107 (1986).

${ }^{21}$ M. J. Kushner, IEEE Trans. Plasma Sci. 19, 387 (1991).

${ }^{22}$ F. Westley, J. T. Herron, R. J. Cvetanovic, R. F. Hampson, and W. G. Mallard, NIST Chemical Kinetics Data base, NIST Standard Reference Data base 17. National Institute of Standards and Technology, Standard Reference Data Program, Gaithersburg, MD 20899.

${ }^{23}$ R. T. Watson, J. Phys. Chem. Ref. Data 6, 871 (1977). 